УДК 338.314

Павлова Олена,

доктор економічних наук, професор, Волинський національний університет імені Лесі Українки, кафедра економіки та природокористування, м. Луцьк, ORCID: 0000-0002-8696-5641, e-mail: pavlova.olena@vnu.edu.ua

Павлов Костянтин, доктор економічних наук, професор, Волинський національний університет імені Лесі Українки, кафедра економіки та природокористування, м. Луцьк, ORCID: 0000-0003-2583-9593, e-mail: pavlovkv@icloud.com

Писанко Сергій, Волинський національний університет імені Лесі Українки, здобувач, м. Луцьк, e-mail: naukoviy@icloud.com

Романюк Роман, Волинський національний університет імені Лесі Українки, здобувач, м. Луцьк,

https://doi.org/10.29038/2786-4618-2021-01-16-27 e-mail: naukoviy@icloud.com

\title{
СТРАТЕГІЯ ТА РИЗИКИ РЕФОРМУВАННІ РИНКУ ЕЛЕКТРОЕНЕРГЕТИКИ В РЕГІОНАХ УКРАЇНИ
}

Охарактеризовано електроенергетичне середовище, яке деформоване монопольними структурами та тотальним контролем по ціноутворенням. Наведено приклад європейської моделі реформування електроенергетичного ринку, що базується на прозорості та доступності споживачів до електроенергетичних послуг. На цій основі з'ясовано цілі та вектори реформування регіональних ринків електроенергетичних послуг. Передбачено, що процес реформування мав би бути здійснений на поєднанні організаційних, економічних, технічних, соціальних та інших цілей. 3'ясування переваг та недоліків при реформуванні електроенергетичного ринку регіону та країни відображено в авторській методиці SWOT-aналізу. Запропонований замкнений цикл реформування електроенергетичного ринку, який охоплює взаємозамінне поєднання таких компонент: регіональні електроенергетичні мережі, ринкове середовище, Інформаційне середовище, фінансово-кредитне забезпечення, інтегрування, трудові ресурси, комунікаційні зв'язки. Окреслено вектори подальшого реформування.

Ключові слова: електроенергетичний ринок, ринкове середовище, електроенергетичний ресурс, об'єднана енергетична система.

Павлова Елена,

доктор экономических наук, профессор, Волынский национальный университет имени Леси Украинки, кафедра экономики и природопользования, г. Луцк

Павлов Константин, доктор экономических наук, профессор Волынский национальный университет имени Леси Украинки, кафедра экономики и природопользования, г. Луцк 


\title{
Писанка Сергей, \\ Волынский национальный университет имени Леси Украинки, соискатель, г. Луцк, \\ Романюк Роман, \\ Волынский национальный университет имени Леси Украинки, соискатель, г. Луцк,
}

\section{СТРАТЕГИЯ И РИСКИ РЕФОРМИРОВАНИЯ РЫНКА ЭЛЕКТРОЭНЕРГИИ В РЕГИОНАХ УКРАИНЫ}

\begin{abstract}
Охарактеризованы электроэнергетическое среду, деформированное монопольными структурами и тотальным контролем по ценообразованием. Приведён пример европейской модели реформирования электроэнергетического рынка, основанный на прозрачности и доступности потребителей к электроэнергетическим услугам. На этой основе выяснено цели и векторы реформирования региональных рынков электроэнергетических услуг. Предполагается, что процесс реформирования должен быть осуществлён на сочетании организационных, экономических, технических, социальных и других целей. Выяснение достоинств и недостатков при реформировании электроэнергетического рынка региона и страны отражено в авторской методике SWOT-анализа. Предложенный замкнутый цикл реформирования электроэнергетического рынка, который охватывает взаимозаменяемо сочетание таких компонентов: региональные электроэнергетические сети, рыночная среда, Информационная среда, финансово-кредитное обеспечение, интегрирования, трудовые ресурсы, коммуникационные связи. Определены векторы дальнейшего реформирования.
\end{abstract}

Ключевые слова: электроэнергетический рынок, рыночная среда, электроэнергетический ресурс, объединённая энергетическая система.

Pavlova Olena, Doctor of Economics, Professor,

Lesya Ukrainka Volyn National University, Department of Economics and Nature Management, Lutsk

Pavlov Konstantin, Doctor of Economics, Professor, Lesya Ukrainka Volyn National University, Department of Economics and Nature Management, Lutsk

Pysanko Sergey, Lesya Ukrainka Volyn National University, getter, Lutsk

Romanyuk Roman, Lesya Ukrainka Volyn National University, getter, Lutsk

\section{STRATEGY AND RISKS REFORMING THE ELECTRICITY MARKET IN THE REGIONS OF UKRAINE}

Introduction. Competitiveness implies a free choice of suppliers by consumers, absence of barriers to the market of supply and sale. The new European format of the electricity market model creates new challenges and threats to the functioning of electricity market enterprises in terms of transparent and objective conditions for access to consumption and operation of electricity networks, unbiased accelerated development of the electricity market to the dynamics of the economic system. Reforming the electricity market combines the processes of achieving organizational, economic, 
technical, social, and environmental goals. However, this combination has different consequences and risks associated with minimizing costs. Clarification of long-term goals and objectives requires a comprehensive approach to the analysis of the electricity market in the following areas: the formation of reform priorities, outlining the benefits and risks, assessing the likely risks of the environment.

The purpose of the article. The purpose of this article is to determine the most optimal strategy and the most probable risks that may arise in the processes of formation of the electricity market both in the regions of the state and nationwide.

Results. One of the most important problems of the system operator in ensuring its independence and mutual respect for all market participants. To this end, the following measures are legally justified: procurement of related services on a competitive basis; transparent information of the available list of related services, their volumes, cost, terms, and requirements to suppliers; formation of accounting for the cost and revenue component in the implementation of the centralization of dispatch management from other activities; formation of access to the capacity of interstate electric networks by conducting electronic auctions; submission of the UES development plan to the Cabinet of Ministers of Ukraine for consideration even in case of disagreement of the interesting instances. However, strengthening the role of the system operator does not ensure its complete independence from external risks. Liberalization of the electricity market takes into account the availability to the wholesale market of other participants who can directly enter into agreements with generation companies and sell electricity to the retail market. Such participants are usually large industrial consumers. At the same time, the retail market is creating a so-called competitive environment, which is an alternative to the existing "oblenergo". The formation of consumer choice will further affect the price and quality and transparency of competitive relations.

Conclusions. The investment component of the region will grow only if the electricity market is reformed. However, the processes of introduction of a new model of the electricity services market are formed in a short time, the introduction and adoption of legislation, the implementation of organizational and structural changes, software testing. Nevertheless, the processes of reforming the electricity services market are an integral attribute of the region's integrated investment policy.

Keywords: electricity market, market environment, electricity resource, integrated energy system.

Постановка проблеми та їі значення. Конкурентоспроможність передбачає вільний вибір споживачами постачальника, відсутність бар'єрів до ринку постачання та збуту. Новий європейський формат моделі електроенергетичного ринку формує нові виклики та загрози функціонування підприємств електроенергетичного ринку, що стосується прозорих та об'єктивних умов досткпубдо споживання та експлуатації електроенергетичних мереж, неупереджений прискорений розвиток електроенергетичного ринку до вимог динамічності економічної системи.

Реформування електроенергетичного ринку поєднує і собі процеси досягнення організаційних, економічних, технічних, соціальних та екологічних цілей. Однак це поєднання обумовлює різні наслідки та ризики пов’язані з мінімізацією витрат.

3'ясування перспективних цілей та завдань потребує комплексний підхід до аналізу електроенергетичного ринку в наступних напрямах: формування пріоритетів реформування, окреслення переваг та ризиків, оцінка ймовірних ризиків зовнішнього середовища.

Аналіз останніх досліджень і публікацій. Скупість кінцевих обрахунків пояснює велике коло дослідників, серед них: В. Лагодієнко, О. М. Павлова, К. В. Павлов, Л. Беляєв та інші. Однак, сучасність глобалізаційного розвитку отримує все більше значення електроенергетичних ресурсів. Окрім того, існує необхідність комплексного підходу до інвестиційно-інноваційних процесів електроенергетичної галузі регіону та визначення організаційно - економічних векторів національної електроенергетичної стратегії.

Мета і завдання дослідження. Метою даної статті є визначення найбільш оптимальної стратегії та найбільш імовірних ризиків, що можуть виникнути в процесів формування електроенергетичного ринку як в регіонах держави, так і в загальнонаціональному масштабі

Викладення основного матеріалу та обгрунтування отриманих результатів дослідження. Взаємодія чинників впливу електроенергетичного ринку регіону методично відображає переваги та недоліки, яке варто відобразити в стратегічному методі SWOT-аналізу (Табл. 1). 
SWOT-аналіз електроенергетичного ринку України

\begin{tabular}{|c|c|}
\hline сторони & \\
\hline 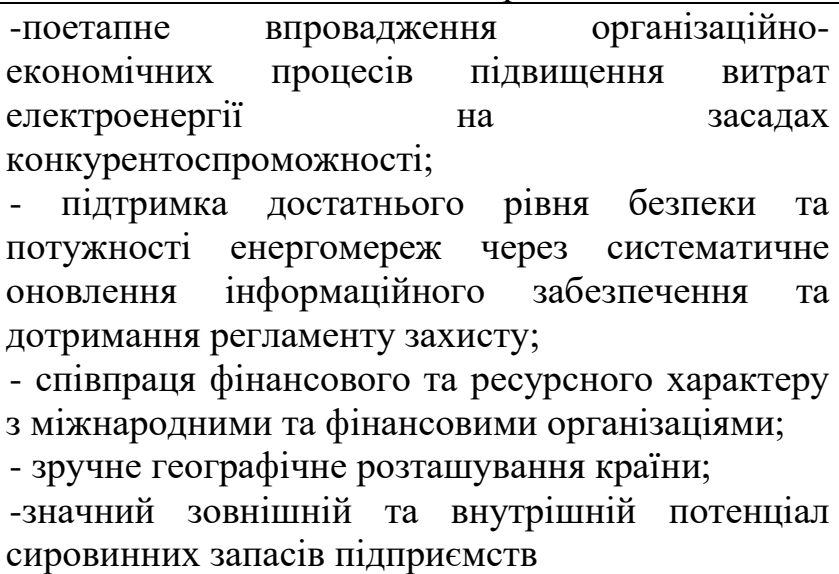 & $\begin{array}{l}\text { - обмеження експортного потенціалу в зв’язку з } \\
\text { несприятливими економічними та політичними } \\
\text { критеріями; } \\
\text {-недосконалість нормативно-правового базису; } \\
\text { - монопольний тиск в секторах генерування та } \\
\text { розподілу електричної енергії; } \\
\text { - низький рівень етичних норм та культурного } \\
\text { обізнання до споживання; } \\
\text {-зношеність мережевого та галузевого фонду; } \\
\text {-підпорядкованість регулятору НКРЕКП, не } \\
\text { прозоре тарифоутворення; } \\
\text { - наявність бюрократичних перепон та відсутність } \\
\text { дієвих бізнес процесів }\end{array}$ \\
\hline & \\
\hline $\begin{array}{l}\text {-диверсифікаційні джерела постачання сировини } \\
\text { для ТЕЦ та АС; } \\
\text {-співдружність з міжнародними організаціями по } \\
\text { формуванню власного паливно-енергетичного } \\
\text { фонду та регулювання надлишку ядерних } \\
\text { відходів; } \\
\text {-формування та забезпечення комплексів } \\
\text { автоматизованої передачі електроенергетичних } \\
\text { ресурсів; } \\
\text {-формування стратегії розвитку відновлювальних } \\
\text { джерел енергії; } \\
\text {-покрокова інтеграція вимог та стандартів ЄС до }\end{array}$ & $\begin{array}{l}\text {-відсутність потрібних умов для інвестиційно- } \\
\text { стимулюючого середовища; } \\
\text {-не прозорі та ворожі відносини між РФ та } \\
\text { Україною; } \\
\text {-ймовірність в односторонньому порядку } \\
\text { від’єднатися від електроенергетичної системи } \\
\text { Білорусії та Росії; } \\
\text {-політичні лобіювання інтересів монополістів; } \\
\text {-низький рівень платоспроможності споживачів } \\
\text { електричної енергії }\end{array}$ \\
\hline
\end{tabular}

Удосконалено автором на основі [1].

Окрім того, існують певні основні реформуючі напрями, які потребують негайних змін та вдосконалень. До них слід віднести об'єкти регіональних електроенергетичних мереж, ринкове Інформаційне середовище, фінансово-кредитне забезпечення, інтегрування, трудові ресурси, комунікаційні зв'язки.

1. Регіональні електроенергетичні мережі знаходяться в зношеному стані та $є$ вимушеними об'єктами інвестиційного спрямування. Тому основними цілями реформування в цьому напрямі має стати: підвищення рівня надійності системи безпеки експлуатації електроенергетичного сполучення та транспортування енергетичних ресурсів; перегляд витрат 3 метою усунення зайвих витрат по обслуговуванню системи;

2. Ринкове середовище. Бажана ситуація га будь-якому ринку, в тому числі на ринку електроенергетичних послуг. Досягнення ринкової конкуренції є можливим за умови досягнення балансу на ринку супутніх послуг, роз’єднання адміністрування комерційного обліку і розрахунків, які призначенні для активного споживання [6];

3. Інформаційне середовище. Необхідність враховувати осучаснений технологічний базис $є$ також вектором реформування ринку на конкуруючих засадах. Впровадження сучасних інформаційно-технічних технологій дозволить балансувати енергетичну систему в реальному просторі, автоматизувати обліково-фінансові розрахунки суб'єктів ринку, здійснювати облік електроенергії, контролювати платежі, забезпечувати належну якість диспетчеризації ОЕС;

4. Фінансово-кредитне забезпечення $є$ неодмінною умовою реформування електроенергетичного ринку. Передбачає пошук найбільш ефективного напряму фінансування інвестиційних програм, 
формування нової методики RAB-тарифу для уникнення його шокового підвищення, зниження операційних витрат, зростання амортизаційних відрахувань;

5. Інтегрування. $€$ сегментом досягнення технологічної спрямованості об'єднаної енергетичної системи України та регіонів до об’єднання 3 Європейською мережею системних операторів транспортування електроенергії в Європі (ENTSO-E) 3 можливим обміном потужностями та ізолюванням від інших країн-учасниць. Це також стимулює організований контроль та структурованість будівництва осередків відновлювальних джерел енергії га засадах практики «зелених» аукціонів;

1 Трудові ресурси. Підвищена продуктивність праці, модернізація системи проплати, мотивація розвитку персоналу та комплексний підхід навчання ;

2 Корпоратизація. Важливий процес корпоратизації компанії через перетворення державного підприємства у приватне з урахуванням елементів корпоративного управління та елементів соціальної відповідальності;

3 Комунікаційні зв'язки. Дуже важливі для безперебійності в постачанні, аналізі інформації. Потребують постійного вдосконалення внутрішньої, зовнішньої та міжнародної комунікації в контексті розробки нової інформаційної політики та значної популяризації.

Тому стратегія реформування електроенергетичного ринку України нагадує замкнений цикл важливих компонент його діяльності (Рис. 1).

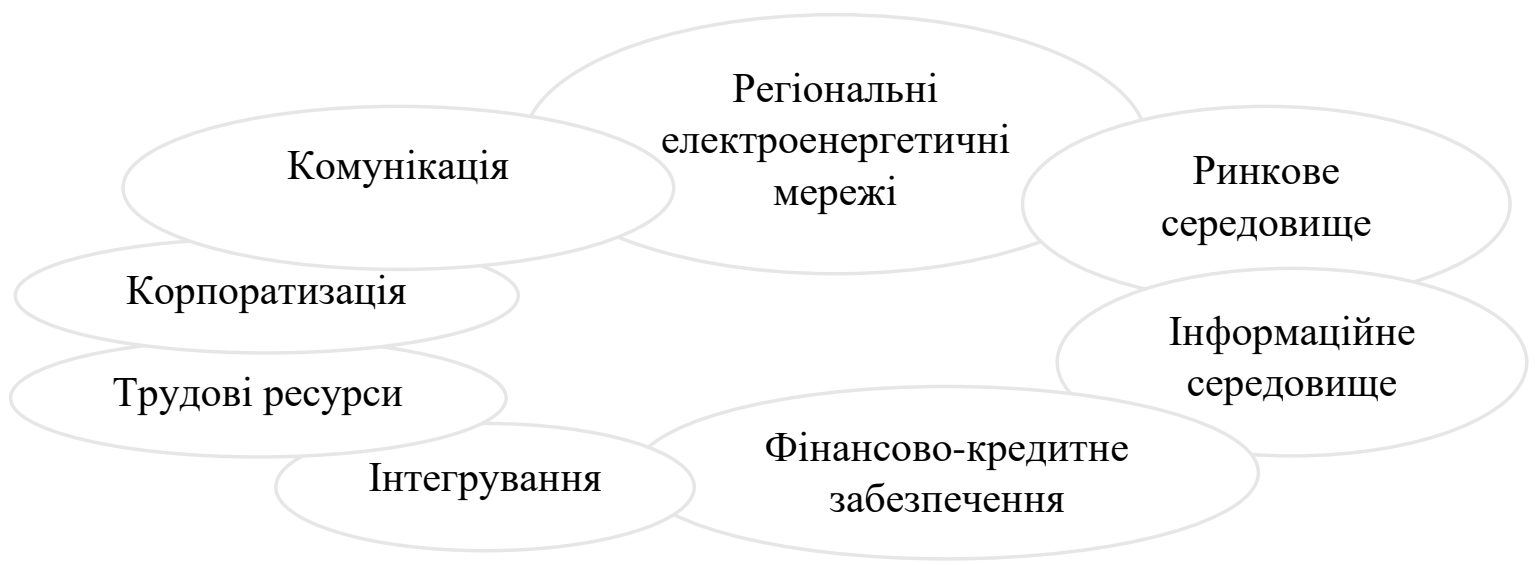

Рис.1. Замкнений цикл стратегії формування електроенергетичного ринку

Отже, в площині консолідації зв'язків 3 європейськими країнами відносно принципів реформування слід дотримуватися таких основних цілей:

- дотримання прозорих конкуруючих умов не лишень в сфері виробництва, але й у сфері постачання електроресурсів між регіональними електроенергетичними ринками;

- підвищення рівня внутрішньої та водночас зовнішньої безпеки постачання енергоресурсів шляхом систематичного процесу модернізації технологічного переоснащення об'єктів «інфраструктурного сполучення» тощо;

- підвищення якісного показника наданих суб'єктами регіональних електроенергетичних ринків послуг;

- обмеження деструктивного впливу діяльності електроенергетичної галузі на навколишнє середовище;

- формування системи ціноутворення адаптивної для споживачів;

- продовження організаційного та нормативно-законодавчого інтегрування регіональних електроенергетичних ринків в європейський енергетичний простір [7].

Виходячи 3 найбільш ефективного варіанту реформування, який зосереджується в основному в імплементації правових та директивних засад, а також наслідування певних етапів досвіду країн Європейського Союзу слід окреслити основні елементи трансформації регіональних електроенергетичних ринків: 
- ринок прямих поставок електроенергетичних ресурсів, який забезпечується через двосторонні договори купівлі-продажу між основними суб'єктами та регіональних електроенергетичних ринках. Для основних суб'єктів відносяться безпосередні виробники електричної енергії (ТЕС, ТЕЦ, АЕС), постачальники безпосередні споживачі (договори укладаються на біржових та позабіржових умовах);

- динамічний електроенергетичний ринок (відхилення фактичної діяльності від планової) узгодження, яке надає можливість задоволення фактичних потреб споживачі споживачів електроенергетичних ресурсів шляхом динаміки основних елементів, які були передбачені двосторонніми угодами з подальшим продажем з аукціону (спот-ринку) ;

- ринок супутніх послуг - послуги супутнього характеру, які надаються суб'єктом регіональних оптових ринків зв умов конкуренції на засадах надійності, безпечності достатнього рівня якості електроенергетичного постачання споживачам (за умов систематичного моніторингу та обліку електроенергетичних ресурсів) [15].

За таких умов оновлена модель реформування електроенергетичних ринків регіону покликане формувати необмежений доступ до електроенергетичних мереж нових суб'єктів, формувати і надалі прозоре конкуруюче середовище секторів генерації та розподілу електричної енергії.

Процес реформування передусім має врахувати smart-технологічний сценарій, зв якого слід розробити автоматизовану систему диференційованого обліку електроенергетичного ресурсу, доступ до обміну даних, що дозволить періодично відслідковувати рух кожної кіловат-години на території України. Окрім того міжнародні норми потребують формування моделі динамічного ринку електроенергії [4].

Однак ці зміни відбуваються вкрай повільно, що пов’язано 3 рядом чинників, які гальмують процеси лібералізації конкурентного середовища, укладання договорів щодо прямих поставок, безпечне енергетичне постачання, виважену цінову політику та прозоре тарифоутворення. Формування конкурентного середовища вже по своїй суті є джерелом зіткнення інтересів різних суб'єктів господарювання та появу ризикових ситуацій. Загалом взаємодія між учасниками на регіональному електроенергетичному ринку має наступний вигляд (Рис 2).

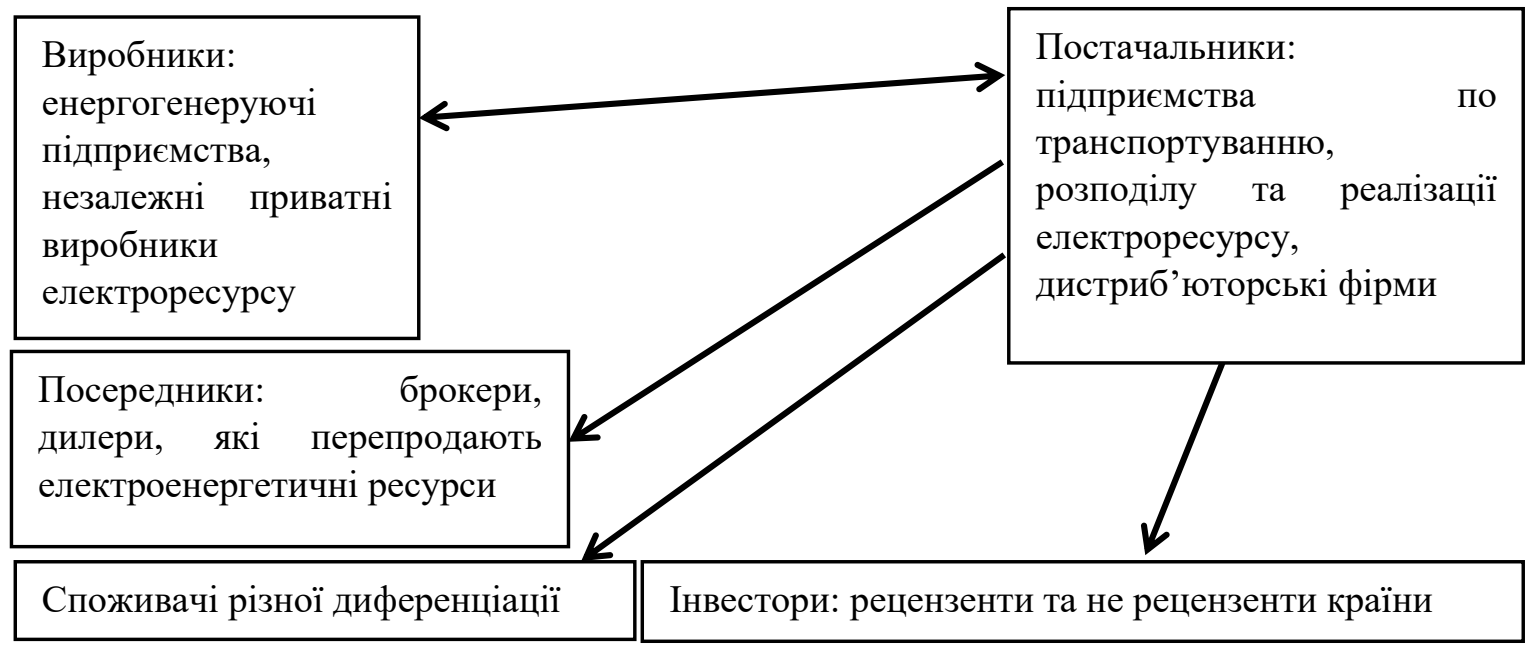

Рис 2. Учасники регіональних ринків електроенергї. Удосконалено автором на основі [3].

Однак, будь-яка реформація по своїй суті матиме певні наслідки для регіональних ринків електроенергії, це акумулюється в наступному:

- деформація конкуруючої моделі усіх секторів економіки та перерозподілу впливу від одних монополістів до інших;

- підвищення тарифів на електроенергію;

- політико-олігархічне лобіювання інтересів сторонніх осіб і регулюючій функції даного ринку;

- дисбалансування функцій між структурними підрозділами ОЕС (об'єднаної енергетичної системи [8]. 
Щодо першого наслідку, який стосується деформації конкуруючої моделі усіх секторів економіки та щ перетікання впливу від одних монополістів до інших появляється в тому що ще досі не реалізовано постанову Кабінету Міністрів та відповідний Закон України «Про ринок електричної енергії». Оскільки дані законопроекти дозволяють врахувати вимоги Третього енергетичного пакету в результаті чого обленерго зобов'язаний розділити діяльність розподілу від діяльності постачання електроенергетичних ресурсів. Це обумовлює розмежування сфер впливу між двома компаніями за зазначеним функціоналом. Перша компанія стане оператором системи розподілу (ОСР) та забезпечуватиме експлуатацію, технічне обслуговування та подальший розвиток та вдосконалення системи розподілу електроенергії. Друга компанія стає оператором системи передачі (ОСП), яка займатиметься продажем безпосереднім споживачам право на користування електроенергією, які постачатимуться мережевим способом. Однак в даному випадку Закон України створює передумови не для вирішення проблеми монополізації, а для ії посилення, лишень збільшуючи чисельність монополістів на даному ринку. Тому дуже важливо дотримуватися векторної європейської націленості, що дозволить обмежити тотальний контроль пануючих суб'єктів, врахувати зацікавленість споживача шляхом формування імпортної конкуренції електроенергетичними ресурсами та стабілізація цін га даному ринку [13].

Стосовно другого наслідку: підвищення тарифів на електроенергію, роздрібний ринок електроенергії України керується новою редакцією Закону України «Про ринок електричної енергії» - 13.04.2018 p. № 2019 VIII) та спрямований на імплементацію основних директивів СС 2009/72/ЕC та забезпечується постачальниками: 25 постачальників універсальної послуги за регульованим тарифом, 33 постачальники за нерегульованим тарифом, які $\epsilon$ приватними компаніями по перепродажу електроенергії. НКРЕКП, будучи основним регулятором діяльності сфери електроенергетики та комунальних послуг здійснює регулювання тарифів для усіх підприємств окрім підприємств нерегульованого тарифу, які постачають електроенергію в основному не побутовим споживачам на конкурентних засадах за договірними цінами. Негативним проявом ціноутворення на роздрібному ринку $\epsilon$ занадто високий рівень перехресного субсидіювання промисловими споживачами вартісної цінності електроресурсу, який продається окремим категоріям споживачів за фіксованими цінами. Загальна сума втрат від компенсації енергопостачальним компаніям в 2020 році становила млрд. грн. що на порівняно з 2019 роком [14].

Попри все тариф на електроенергетичні послуги в регіонах України вважається самим найнижчим в Європі. Однак доходи теж в самій країні є найнижчими.

На сьогодні, тарифоутворення на електричну енергію, які надаються у ДП «Енергоатом» встановлюються НКРЕКП за методом «Витрати +», що не створює мотивацію підприємствам для вивільнення частини трансакційних витрат тому що обсяг прибутку згідно даної методики практично не залежить від ефективної діяльності підприємства.

Тому одним із інтегруючим моментів зближення $з$ європейським енергетичним ринком має стати реалізація тарифного підходу регулювання природніх монополій за методикою «норми прибутку на інвестиційний капітал» при врахуванні показників якості послуг. Тобто перед Україною стоїть питання застосування методів порівняльного аналізу в рейтингуванні компаній та врахуванні якісного рівня послуг.

Сам Кабінет Міністрів України підтримує метод стимулюючого ціноутворення, проте не переконливо ставиться до проєкту ухваленого НКРЕКП від 27.07.2017 року відносно обгрунтовування доцільності його застосування в промисловості, що може вплинути на скачок цін.

Очікується що реформування ринку електроенергетичних послуг може вплинути на підвищення тарифів для населення. Це можливо внаслідок переоцінювання вартості активів ДП «НБК Укренерго» внаслідок чого прогнозується різке підвищення амортизаційних відрахувань що спричинить зростання тарифу. Окрім того, практика деяких країн, які лібералізували свої електроенергетичні ринки доводить що регулювання цін для пересічних споживачів та ціноутворення підприємствами, які генерують енергію веде до збоїв у забезпеченні електроресурсами та має ознаки старої регульованої моделі [5].

Згідно третього аспекту політично-олігархічного лобіювання інтересів сторонніх осіб в регулюючій електроенергетичному ринку слід виділити такі аспекти. Вагомим аргументом $є$ недосконалість чинного законодавства, не враховує динаміку змін власності для описаного 
оператора (державна форма власності), ціноутворення, яке формується зовнішніми чинниками. Тобто, ціноутворення формується з централізованого диспетчерського управління та в межах тарифу регламентованого НКРЕКП. Однак, беручи до уваги «вразливість» регулюючого органу відносно політичних особистісних бізнесових вимог, залишається сумнівною економічна обгрунтованість встановлених тарифів.

Дизбалансування функцій між структурними підрозділами об'єднаними енергетичними аспектами. Загалом ринок є елементом вільного партнерського обміну результатами діяльності. Однак ситуація має певну особливість га ринку електроенергії за умови коли кожен виробник чи постачальник який має відповідати за власний небаланс (відхилення показників виробництва та споживання). Формуючи двосторонні контракти або реалізуючи електроенергію на ринку на добу наперед, постачальники та виробники повинні забезпечити своє споживання та виробництво в певні години на відповідному рівні.

Проте забезпечити відповідність умовам контракту практично неможливо, оскільки є ряд непередбачених обставин: погіршення погодних умов, зміна фактичного обсягу генерації вітровими та сонячними електростанціями, модернізація генеруючого обладнання [12].

Тому відповідальними за баланс ОВС України загалом покладено на оператор системи передачі ДП «НЕК Укренерго». Даний орган зобов'язаний створювати резервні запаси та ринок суміжних послуг. Такі послуги, формуються на засадах платності, тариф якого регулюється вторинним законодавством [10].

П'ятим аспектом є зменшення обсягів інвестування в модернізацію та розвиток об'єктів електроенергії.

В Україні середній термін експлуатації розподільчих електромереж перевищує 45 років, зношеність інфраструктури стає 60-85\%, що спричиняє виникнення проблем із забезпеченням безперебійності поставок електроенергії споживачам останніми роками у вітчизняні обленерго було інвестовано близько 15 млрд. грн. тоді як за планом передбачено 70 млрд. грн.

Прогнози «Асоціації операторів розподільчих електромереж України» передбачають забезпечення надійності безперешкодної поставки електроенергії на модернізацію електромереж близько 25 млрд.

Дієвою в даному напрямі інвестиційного забезпечення є оновлення мережевої інфраструктури можливе шляхом системи стимулюючого тарифоутворення, а також RAB - регулювання системи довгострокового сценарію стратегічного ціноутворення. RAB-регулювання $\epsilon$ можливим шляхом запровадження регуляторної норми доходу за наступним обрахунком: «витрати + повернення інвестованого капіталу+ дохід на інвестований капітал».

Регулювання тарифоутворення $\epsilon$ можливим за рахунок збільшення таких інвестиційних рішень: 1) зростання прибутковості підприємств внаслідок мінімізації витрат; 2) залучення приватного інвестування; 3) збільшення обсягів надання інституційних послуг. Однак $є$ типовим виникнення ризиків, які негативно впливатимуть на об'єкти інвестування. Типовими ризиками є:не ефективний механізм захисту приватних інвесторів, не послідовна та не ефективна політика, недосконале правове законодавство, політичний та бізнесовий вплив, недооцінка активів ДП «НЕК «Укренерго» відносно залучення інвестицій. В цьому напрямку звіт міжнародної компанії «Ernst and Young», «Mapping pioneer utilities regulation in Europe» оцінка власних інвестиційних ресурсів оцінюється незалежним експертом що дозволить зробити ефективнішим RAB - регулятором по активізації фінансового капіталу та захисту інтересів усіх суб’єктів даного ринку.

Тому ефективне реформування електроенергетичного рішення знаходиться в площині таких організаційних та управлінських рішень:

- ефективному та прозорому регулюванню НКРЕКП ;

- розподіл функціональних обов'язків між обласними енергетичними компаніями;

- отримання сертифікованого дозволу на провадження діяльності оператора системи передачі;

- купівля програмного забезпечення ОСР та ОСП;

- удосконалення та укомплектованість технічних заходів в контексті реформ роздрібного електроенергетичного ринку;

- адаптувати усіх суб’єктів ринку до функціонування в принципово нових умовах; 
- ліквідувати механізми перехресного субсидіювання і привести ціни для споживання до економічно обгрунтованих розмірів;

- тотальне вирішення хронічної заборгованості, яка є по всій об'єднаній енергетичній системі.

Чітке визначення цілей та напрямів реформування та зменшення ймовірних ризиків при реформуванні ринку електроенергетики створить в подальшому умови для підвищення якості послуг, обмежить негативні прояви на навколишнє середовище, удосконалення ціноутворення та посилення міжнародної співпраці.

Однак не дивлячись на існуючі аспекти, процеси реформування електроенергетичного ринку величезне значення має організація діяльності яка $є$ складнішою та формується за умов політичнонестабільної ситуації та зовнішньої агресії. Оскільки необхідно змінити модель розвитку електроенергетичного ринку потребує оновлених організаційно-економічних форм за умов неспроможності діючої моделі «єдиний покупець» вирішити нові проблеми, які виникають в електроенергетичному середовищі. Неспроможність існуючої моделі пов'язана 3 специфікою розвитку економіки регіонів: безнадійно непогашені борги між суб'єктами оптового ринку, дефіцитність рахунків поточного погашення, штучне маніпулювання грошових потоків на ринку; недобросовісна конкурентна ситуація, відсутність ринку супутніх послуг; адміністративний тиск в регулюванні ринку, відсутність дієвого механізму кредитних гарантів та ймовірність зменшення ризиків [9].

Оновлена модель $є$ імплементованим сценарієм європейського енергетичного ринку, охоплює такі сегменти ринку:

1. Ринок двосторонніх договорів. Функціонуванню даного ринку обумовлює те, що виробники спроможні реалізувати електроенергію підприємствам по збуту та безпосереднім кінцевим споживачам.

Суб’єкти, які укладають договори: виробники електроенергії, незалежний постачальник, гарантований постачальник, електророзподільне підприємство, кваліфікований споживач.

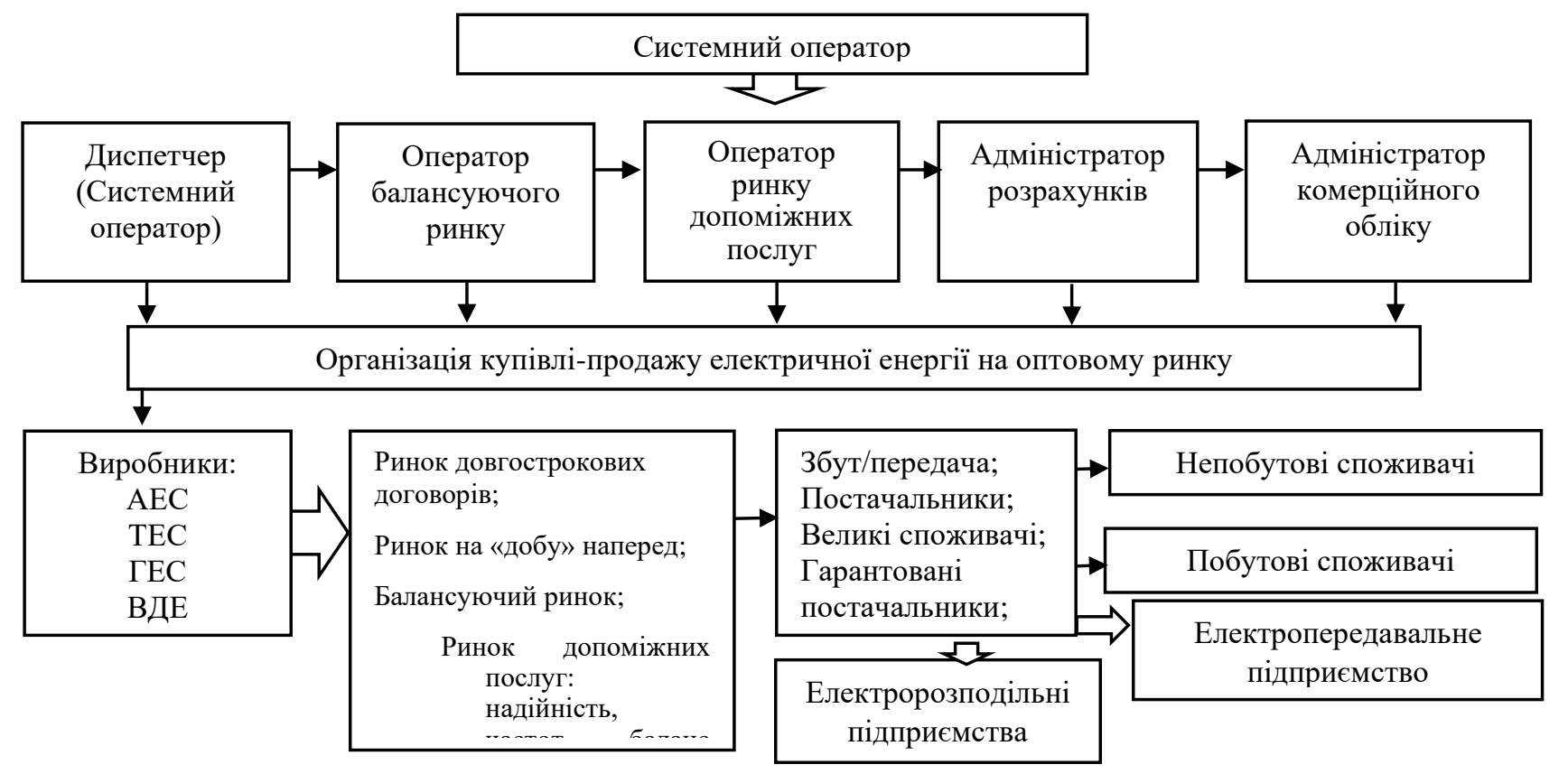

Рис. 3. Схема організації процедури купівлі-продажу електроенергетичних ресурсів на реформованому оптовому ринку, [11].

На ринку двосторонніх договорів відбуваються такі процеси: 1) постачальники електричної енергії загалом покривають більшість потреб у електричних ресурсах; 2) регулятор не втручається в процеси ціноутворення та взаємостосунки між суб'єктами ринку; 3) споживач має право здійснювати операції купівлі-продажу енергетичних продуктів; 4) постачальники є уповноваженими укладати 
прямі двосторонні договори з виробниками на засадах домовленості сторін з метою прогнозування дохо дно-витратної політики в майбутньому.

Організація купівлі-продажу електроенергетичних ресурсів на оптовому реформованому ринку має вигляд, що відображено на рисунку 3.

2. Ринок на «добу наперед». Суб'єкти цього ринку реалізовують електроенергетичні ресурси «на наступний день» через подачу заявок на купівлі (продаж) оператору ринку. Основна мета створення цього ринку є зниження небалансів суб'єктів. Суб'єктами ринку «на добу наперед» $є$ виробник електроенергії, незамінний постачальник, гарантований постачальник електричної енергії за «зеленим тарифом», електророзподільне підприємство, оператор ринку «на добу наперед». Ринок в даному сенсі являє собою біржу, на якій формується єдиний підхід жл ціноутворення на конкурентних принципах взаємодії попиту та пропозиції.

3. Балансований ринок. Загалом організований системним оператором задля досягнення наступних цілей: 1) балансування обсягів пропозиції (експорту та імпорту електроенергії) та обсягів попиту (внутрішнього та зовнішнього) ; 2) впорядкування наявних системних обмежень об'єднаної енергетичної системи України; 3) фінансове регулювання наслідків небалансів електроенергетичної складової. До суб'єктів даного ринку слід віднести: виробників електроенергії, незалежного постачальника, гарантованого постачальника, гарантованого покупця за «зеленим тарифом», системний оператор, адміністратор розрахунків, кваліфікований споживач, за умов набуття ним статусу учасника ринку, який забезпечуватиме дотримання балансу.

4. Ринок супутніх послуг. Системний оператор надає послуги суб'єктам оптового ринку на засадах конкуренції для досягнення надійності, якісного забезпечення послугами споживачів, тощо. Він закупляє ці послуги задля забезпечення сталої та надійної роботи об’єднаної енергетичної системи відповідно до затверджених стандартів.

5. Системний оператор. У вітчизняному законодавчому полі системний оператор $\epsilon$ унітарним або корпоративним підприємством, яке не може змінювати форму власності. Загалом системний оператор виконує такі функції: централізоване диспетчерське управління режимами роботи ОЕС України, забезпечення функціонування балансуючого ринку, забезпечення роботи ринку супутніх послуг, адміністрування розрахунків та комерційного обліку [2].

Однією з найважливіших проблем функціонування системного оператора в забезпеченні його незалежності та взаємоповаги до усіх учасників ринку. Для цього законодавчо обгрунтовано наступні заходи:

- закупівля супутніх послуг на конкурентних засадах;

- прозоре інформування наявного переліку супутніх послуг, їх обсягів, вартості, термінів та вимог до постачальників;

- формування обліку витратної та дохідної складової при здійсненні централізованості диспетчерського управління від інших видів діяльності;

- формування доступу до пропускної спроможності міждержавних електричних мереж шляхом проведення електронних аукціонів;

- внесення на розгляд КМУ України плану розвитку ОЕС навіть у випадку неузгодженості зацікавлених інстанцій.

Однак посилення ролі системного оператора не забезпечує його цілковиту самостійність від зовнішніх ризиків. Лібералізованість електроенергетичного ринку враховує доступність до оптового ринку інших учасників, які спроможні безпосередньо укладати угоди з підприємствами по генерації та реалізовувати електроенергію га роздрібному ринку. Такими учасниками, як правило, $є$ великі промислові споживчі. На роздрібному ринку водночас з боку пропозиції формується так зване конкурентне середовище, яке $\epsilon$ альтернативним існуючим обленерго. Формування вибору споживача впливатиме в подальшому на ціну та якість та прозорість конкурентних відносин.

Висновки і перспективи подальших досліджень. Інвестиційна складова регіону зросте лишень за умови реформування ринку електричної енергії. Однак процеси запровадження нової моделі ринку електроенергетичних послуг формується за стислих термінів, запровадження та прийняття законодавчих актів, здійснення організаційних та структурних перетворень, апробації програмного забезпечення. 
Попри все, процеси реформування ринку електроенергетичних послуг є невід’ємним атрибутом цілісної інвестиційної політики регіону.

\section{Джерела та література}

1. Вільха В. А. Проблеми реформування енергоринку України. Ефективна економіка 20.08.2017 p. URL: https://economynauka.com.ua/index.php.operation.

2. Еколого-економічні засади раціонального природокористування: теорія та практика реалізації: кол. монографія, за редакцією проф. Стрішенець О. М. Луцьк : Вежа-Друк; 2015. 236 с.

3. Купчак В.Р. Павлова О. М. Павлов К. В. Формування та регулювання регіональних енергетичних систем: Теорія, методологія та практика. Монографія.- Луцьк: СПД Гадяк Жанна Володимирівна «Волиньполіграф», 2019.- 346 с.

4. Нова енергетична стратегія України: Безпека, енергоефективність, конкурентоспроможність. URL https://mpe.kmu.gov.ua/minugol/doccatalog/document?id=2452.

5. Павлов К. В. Павлова О. М. Коротя М. І. Регулювання діяльності регіональних газорозподільних підприємств України: монографія. - Луцьк : СПД Гадяк Жанна Володимирівна, друкарня «Волиньполіграф», 2020.-286 c.

6. Павлов К.В. Оцінка конкурентоспроможності регіональних ринків житлової нерухомості України: монографія. Луцьк: ПрАТ «Волинська обласна друкарня», 2018. 482 с.

7. Павлов К.В., Павлова О.М. Формування та регулювання конкурентних відносин на регіональних ринках житла України : монографія. Луцьк : видавництво «Терен», 2019. 542 с.

8. Павлова О. М., Павлов К. В., Якимчук А. Ю., Сорокопуд І. В., Галянт С. Р. Енергетичний ринок західного регіону України. Міжнародний науковий журнал "Інтернаука". Серія: "Економічні науки". 2020. №7. https://doi.org/10.25313/2520-2294-2020-7-6202

9. Постанова НКРЕКП від 26.05.2018 р. № 556 «Про встановлення «зелених» тарифів на електричну енергію для приватних домогосподарств» URL: http:www.nerc.covi.ua/.

10. Постанова НКРЕКП від 26.06.2018 р. № 505 «Про встановлення зелених тарифів га електричну енергію та надбавки до «зелених» тарифів за дотриманням рівня використання обладнання українського виробництва: URL: http:www.nerc.ccov.ua.

11. Слупський Б. В. Основні моделі ринків електроенергії та особливості їх державного регулювання: порівняльний аналіз. URL: http://archive.nbuv.gov.us/portalisoc.Gum/Dums/2009_3109.

12. Стрішенець О.М, Павлов К.В. Особливості конкурентних відносин на регіональних ринках нерухомості. Науковий вісник Ужгородського університету. Серія: Економіка. Ужгород: Вид-во УжНУ «Говерла», 2016. Вип.1 (47). Т.2. С. 35-38.

13. Стрішенець О.М. Павлов К.В. Механізм фінансово-кредитного забезпечення енергоефективних заходів на об'єктах ЖБК та ОСБ. Кліматичні фінанси: моногр. Луцьк : Вежа-Друк, 2017. С. 165-183.

14.Трансформація ринку електроенергії України: шлях від виробника до споживача. URL:https://issuu.com/uaenergy/docs/poneer_market_holikova.

15. Фартушний I. Д. Трансформація ринку електроенергії України за умов європейської інтеграції: URL: http://ied.kpi.ua/wp-content/uploads/2017/03/.

\section{References}

1. Vilkha V. (2017) Problemy reformuvannia enerhorynku Ukrainy [Problems of reforming the energy market of Ukraine]. Efektyvna ekonomika - Effective economy. URL: https://economynauka.com.ua/index.php.operation [In Ukrainian].

2. Strishenets O. (2015) Ekoloho-ekonomichni zasady ratsionalnoho pryrodokorystuvannia: teoriia ta praktyka realizatsii: kol. monohrafiia [Ecological and economic principles of rational nature management: theory and practice of implementation: col. Monograph]. Lutsk: Tower-Print. 236 [In Ukrainian].

3. Kupchak V., Pavlova O., Pavlov K., (2019) Formuvannia ta rehuliuvannia rehionalnykh enerhetychnykh system: Teoriia, metodolohiia ta praktyka. Monohrafiia [Formation and regulation of regional energy systems: Theory, methodology and practice. Monograph]. Lutsk: SPD Gadyak Zhanna Volodymyrivna "Volynpolygraph". 346 [In Ukrainian].

4. Nova enerhetychna stratehiia Ukrainy: Bezpeka, enerhoefektyvnist, konkurentospromozhnist [New energy strategy of Ukraine: Security, energy efficiency, competitiveness]. URL https://mpe.kmu.gov.ua/minugol/doccatalog/document?id=2452 [In Ukrainian]. 